\title{
Aanpassing- en hanteringstrategieë van bestaansboere in die Richtersveld, Suid-Afrika
}

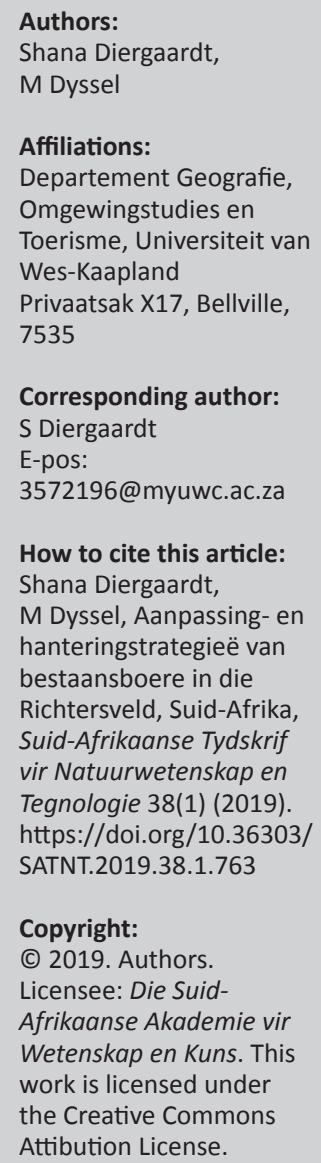

Coping and adaptation strategies of subsistence farmers in the Richtersveld, South Africa: The Richtersveld is an area known for its mountainous desert landscape and receives very low annual rainfall. Despite this, there are a lot of subsistence livestock farming activities. This study seeks to determine whether the nature and extent of subsistence livestock farmers' adaptation and coping mechanisms change in response to continuing drought.

Bestaansboere, woonagtig in verskeie dorpe in die Richtersveld soos Eksteenfontein, Lekkersing en Khuboes, sowel as nabygeleë dorpe soos Port Nolloth en Alexanderbaai, gebruik die Richtersveld-area vir weiding vir verskeie soorte vee. Hierdie veesoorte sluit beeste, skape en bokke in. Die Richtersveld, 'n droë, semi-woestynagtige landskap, is geleë in die Noord Kaap, Suid Afrika, en word gekenmerk deur baie lae reënval. Baie van die boere in dié area is primêr van boerdery vir oorlewing afhanklik. Boerdery in die word van generasie tot generasie oorgedra, wat beteken dat boere voortdurend nuwe strategieë moes vind om by die dorre omgewing aan te pas. Die Richtersveld ontvang meestal winterreën, alhoewel daar sommige jare baie min of geen reën voorkom nie. Dié lae reënval, saam met die onlangse verergerde droogte, maak dit belangrik om te kyk na boere se aanpassing- en hanteringstrategieë, sowel as hoe hierdie strategieë oor die jare kon verander of konstant gebly het. Deur te fokus op die verband tussen gedokumenteerde reënvaldata en boere se persepsies oor droogteperiodes, kan 'n breër begrip van hierdie spesifieke onderwerp verkry word. Die doelwitte vir hierdie studie is om boere se aanpassing by en hulle hantering van droogtes oor die algemeen te heroorweeg, om hierdie strategieë met die omgewings- en sosio-ekonomiese toestande in hierdie gebied in verband te bring, om 'n studie in dié gebied te doen om die verhouding tussen die droogte en boerdery te ondersoek en om hierdie data te ontleed en gevolgtrekkings daaroor te maak. Die studie word onderlê deur 'n kwalitatiewe en kwantitatiewe ondersoek, waarin onderhoude met boere in die dorpe Eksteenfontein, Khuboes en Port Nolloth gevoer is. Hierdie inligting is geanaliseer en met die reënvaldata van die gebied vergelyk. Dit was ook belangrik om die boere se persepsies oor droogte te oorweeg omdat dit bepaal hoe hulle optree om by die droogte aan te pas en hoe hulle dit hanteer.

Nota: 'n Seleksie van referaatopsommings: Studentesimposium in die Natuurwetenskappe, 25-26 Oktober 2018, SA Akademiegebou, Pretoria, Suid-Afrika. Gasredakteurs: Prof Rudi Pretorius (Departement Geografie, Universiteit van Suid-Afrika); Prof Chris Swanepoel (Departement Besluitkunde, Universiteit van Suid-Afrika); Me Andrea Lombard (Departement Geografie, Universiteit van Suid-Afrika) 